Olson also has been appointed to a number of APSA committees, including the Committee on Departmental Services, the Victoria Schuck Award Committee (as chair), and the Alice Paul Award Committee for the Women's Caucus, and she will organize the New Political Science (NPS) Section program panels for next year. In 2009, she received the Charles A. McCoy Career Achievement Award from NPS.

\section{COUNCIL MEMBER, 2010-12}

\section{Dara Strolovitch, University of} Minnesota, Twin Cities

Dara Strolovitch is an associate professor of political science at the University of Minnesota. She received her BA from Vassar College and her Ph.D. from Yale University. Her teaching and research focus on interest groups and social movements; representation; and the intersecting politics of race, class, gender, and sexuality in the United States. Her 2007 book, Affirmative Advocacy:
Race, Class, and Gender in Interest Group Politics (University of Chicago Press, 2007), won the APSA's Kammerer Award, the Political

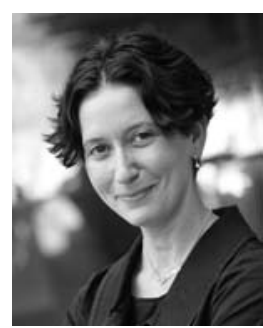

Organizations and Parties section's Epstein Award, the American Sociological Association's Race, Gender, and Class section's Distinguished Contribution to Scholarship Award, and the Association for Research on Nonprofits and Voluntary Action/Independent Sector's Hodgkinson Prize. Her work has also appeared in several edited volumes and in journals including the Journal of Politics, American Journal of Sociology, National Women's Studies Association Journal, Social Science Quarterly, and the Du Bois Review. She has held fellowships at the Brookings Institution and Georgetown University, and she has received grants from sources including the National
Science Foundation and the Social Sciences and Humanities Research Council of Canada. With Burdett Loomis and Peter Francia, she is currently co-editing the CQ Guide to Interest Groups and Lobbying. Her current research examines the effects of rhetorics of crisis and catastrophe on advocacy organizations.

Dara has served as program co-chair for APSA's Race and Ethnic Politics section (2010), as chair of the MPSA's Committee on Nominations (2010), and as a member of the APSA's LGBT Status Committee. She has also served on the MPSA's Breckenridge Award committee, the Political Organizations and Parties section's Epstein Award committee, and the Qualitative and Multi-Method Research section's George Award committee. She serves on the Perspectives on Politics editorial board and served previously on the board of the Journal of Politics.

\title{
Congress from the Inside: U.S.-Africa Foreign Policy and Black Ethnic Politics
}

\author{
Menna Demessie, University of Washington California Center
}
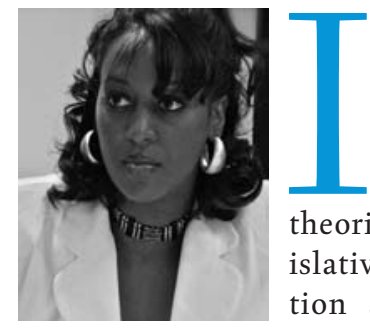
$\mathrm{n}$ addition to the ardent call for political scientists to broaden their theories about legislative representation and behavior to include a broader analysis of the everyday operations of Congress, the call for a more nuanced approach to the study of race and ethnic politics resonates just as deeply. With the emergence of black ethnic caucuses such as the Ethiopia and Ethiopian American Congressional Caucus (EEAC) and the subsequent election of President Barack Obama, African immigrants and their progeny have been made visible to the American polity in ways they have never been before. As an Ethiopian American whose personal and professional interest aims to highlight the signifi- cance of black ethnic political participation and representation in U.S. politics, I found working for Rep. Barbara Lee (D-CA) as an APSA Congressional Fellow to be an extraordinary opportunity to explore how and why African American members of Congress in particular, and other nonblack legislators more broadly, represent their constituents beyond race.

Congressional caucuses invite more complex analyses of black ethnic cleavages within the American polity and date back to 1971 , when the first racial minority group created in Congress, the Congressional Black Caucus (CBC), set a precedent for racial group representation that promoted a for-us-byus strategy of descriptive and substantive representation. Called the "conscience of Congress," the CBC was defined by a sense of community that stretched beyond district lines to serve a national constituency of African Americans (Walton 1994). In an effort to address the needs and interests of African Americans, the $\mathrm{CBC}$ sought to ensure that civil rights legislation would continue to meet the challenges raised by longstanding inequities in voting, housing, education, health care, and legal protection and representation. Other racial minorities followed suit shortly after with the creation of the Congressional Hispanic Caucus (CHC) and the Congressional Asian Pacific American Caucus (CAPAC) in 1976 and 1994, respectively. However, with the influx of African immigrants to the United States, emerging U.S. foreign policy concerns regarding strategic counterterrorism operations in Africa, China's economic expansion, and the HIV/ AIDS epidemic, caucuses have emerged that are composed of members who do not racially or ethnically identify with the group they represent. This situation is no more apparent than with the creation of the EEAC, which was founded and chaired in 2000 by Rep. 
Mike Honda (D-CA), a Japanese-American who also serves as the CAPAC chair. Similarly, Rep. Lee is not only an EEAC member but also currently serves as the CAPAC Healthcare Task Force Chair. Such nuances in black legislative representation reveal the significance of black ethnicity, as well as the potential of what I call "cross-racial representation," or the ability of African American, Asian, white, and Latino members of Congress to collectively represent the interests of racial and ethnic minorities.

As a former CBC chair, the sole vote against authorization for the use of military force following the $9 / 11$ attacks, a founder of the Out of Iraq Caucus and the Out of Poverty Caucus, and the first woman ever elected from the Ninth district of California, Rep. Barbara Lee has boldly gone where few members have gone before. She has maintained strong antiwar and antipoverty initiatives, and the work conducted in her office addresses not only her constituents in California, but several communities across the globe. When I first arrived at her office in Rayburn at the start of the 112th session of Congress, stacks of boxes were lined outside, as many members were moved to new offices after the sweeping Republican takeover of the House in the 2010 midterm elections. After being introduced to a racially diverse legislative staff that reflected her district, I was given a list of Rep. Lee's bills and asked to draft the constitutional authority statement for each piece of legislation that was required by Speaker John Boehner's new House rules. My workspace was set up directly across from Rep. Lee's office and allowed me to tilt my chair back and see who came to visit the office or meet with Rep. Lee on any given day. On some occasions, these visitors were constituents or various organization representatives from her district, and on other occasions, they were fellow or former members, such as Ron Dellums, Rep. Lee's mentor, a CBC cofounder, and a strong antiwar activist and sponsor of the Comprehensive Anti-Apartheid Act of 1986, which imposed sanctions on the South African government.

My first project was working on Rep. Lee and Rep. Bobby Scott's (D-VA) Emergency Unemployment Compensation Expansion Act (H.R. 589), which would extend unem- ployment benefits for jobless workers drastically affected by the recession. By persistent effort, Rep. Lee and Rep. Scott were able to secure a meeting with Speaker John Boehner and Majority Leader Eric Cantor to address the need for unemployment insurance and how to move their bill forward in the Ways and Means Committee. After attending their closed-door meeting on H.R. 589 and witnessing how members dialogue and debate legislation, I realized the need to reevaluate our understanding of political representation to include the significance of legislative behavior.

With respect to her political activism as a member of the Appropriations Committee and the Africa and Global Health Subcommittee on Foreign Affairs, Rep. Lee's leadership in combating the HIV/AIDS pandemic in Africa has made her one of the most influential members of Congress on matters standing of legislative behavior.

Beyond the draw of working in Congress and being able to revisit the similarities and differences between politics in theory and politics in practice on the Hill, Washington, DC, is particularly appealing to me as a scholar of U.S.-African foreign policy because it is also home to one of the largest African immigrant communities in the country. Although the U.S. Census statistics arguably continue to undercount the number of Africans living in the United States, the official numbers indicate that $41 \%$ of the African foreign-born population arrived between 2000 and 2005, with approximately 114,00o African immigrants settling in the DC metropolitan area since 2005 (Wilson 2008). Moreover, African immigrants in the Washington, DC, metropolitan area have taken advantage of their proximity to Capitol Hill. Many do not hesitate to use their lunch break to attend an Afri-

can subcommittee meeting, hearing, or briefing and make their support, condemnation, or observation heard, as with H.R. 5680 , the Ethiopia Freedom, Democracy, and Human Rights Advancement Act, introduced by Rep.

of global health and security, successfully pushing for the "recognition of HIV/AIDS as a national security threat because of its detrimental effect in the areas of trade and social and democratic institutions" (Holtz 2008,111). Additionally, her bipartisan efforts with Rep. Jim Leach (R-IA) in the passage of the World Bank AIDS Trust Fund Act (H.R. 3519) in 2000 set a new direction for U.S.African foreign policy in the twenty-first century and laid the foundation for future legislation aimed at combating HIV/AIDS and poverty, including the President's Emergency Plan for AIDS Relief (PEPFAR) and the Millennium Challenge Account (MCA). Given that Rep. Lee has authored or co-authored every piece of major legislation that deals with global HIV/AIDS issues since her election to Congress, working as an APSA fellow on her staff provided me with intimate access into and knowledge of the daily operations inside and outside of the committee process that not only explain members' voting records and policy positions, but ultimately suggest a far broader scope of representation that political science scholarship must capture to arrive at a more complete under-
Christopher Smith (R-NJ) and sponsored by Rep. Donald Payne (D-NJ), among others. Furthermore, organizations like the Congressional African StaffAssociation (CASA) in Congress have brought particular organizational focus to Congress' approach to U.S.-African foreign policy, while DC-based nonprofit organizations like the Society of Ethiopians Established in the Diaspora (SEED) or the Diaspora African Woman's Network (DAWN) have been instrumental in effectively mobilizing the local African diaspora in ways that empower these individuals to become influential leaders within their respective communities, thereby making black ethnic constituencies that much more visible.

Finally, I have been able to maximize the APSA fellowship experience by teaching an evening U.S.-African foreign policy course at the University of California Washington Center. This experience has been particularly rewarding for me and my students, who benefit from being able to witness politics in action while also discussing the costs and benefits of existing U.S.-African relations and policy. For example, having Prince Erm- 
ias Sahle-Selassie, the grandson of Ethiopian Emperor Haile Selassie, speak to my class about the significance of Ethiopia in the Pan-African movement and its influence on U.S.-Africa foreign policy, as well as his work in Washington, DC, as President of the Crown Council of Ethiopia, makes all the more real the potential for black ethnic politics to shape and reshape the American polity and its policy agenda. Additionally, Secretary of State Hillary Clinton's designation of 2011 as the International Year for People of African Descent has further validated both the political influence of the African diaspora in the United States and the need for the U.S. government to recognize the value of working in partnership with diaspora communities in addressing U.S. foreign policy. My experiences attending the first U.S.-Islamic World Forum held in the United States in mid-February, meeting Secretary Clinton, and hearing her remarks about partnership with the American Muslim diaspora further highlighted for me the potential of and need for diasporic communities to become active agents in promoting robust diplomatic foreign relations with other countries while also being productive and engaged civic participants within American society.

At the end of the day, the APSA Congressional Fellowship affords political scientists the ability to push the epistemological framework of scholarship on Congress in new directions that keep up with the fastpaced nature of congressional policymaking itself. Additionally, the Fellowship challenges political science scholars to revisit the essential function of Congress, which is to represent the interests of its various constituencies.

Political representation has always fascinated me: it is arguably the most important responsibility of legislators, the most important concern of constituents, and the most thoroughly investigated topic in political science, and yet no standard definition exists for it. Although scholars have traditionally understood representation to entail members acting like delegates and voting for constituent interests, other scholars have expanded the notion of representation to include the process or spectrum of activities in which members involve themselves during their term: drafting or cosponsoring bills, making public appearances and speeches, building coalitions with colleagues, joining caucuses and committees, setting agenda, taking up issues, and visiting their districts (Smith 1981; Hammond 1998; Singh 1998; Canon 1999; Fenno 2000; Fenno 2003; Cox and McCubbins 2005; Sulkin 2005). Having witnessed members spending significant amounts of time attending briefings and hearings, leading tele-town hall discussions, meeting with individuals and organizations about their cause, fundraising, agreeing to media interviews as a vehicle to message their agenda, or using race- and ethnic-based caucuses to address the interests of specific communities, there is no question in my mind that political science scholarship must continue to broaden its analyses of descriptive and substantive representation to accurately reflect the changing nature of political representation.

Finally, given the increase in race- and ethnic-based congressional caucuses, the need to expand our ideas of congressional representation beyond roll-call voting, especially in regards to the collective group representation of racial and ethnic minorities in Congress, is apparent. The fact that members are voluntarily uniting and engaging as a group to represent the interests of Africans and other ethnic groups at an increasing rate further suggests that representation literature needs to look beyond the fact that caucuses have no legislative power and pay close attention to how legislators nonetheless use caucuses to influence and shape policy. Capturing the motivations and political preferences of these untapped constituencies is not only necessary for explaining diversity within the U.S. black population, but also suggests the need for a reevaluation of the relationship between immigrants and Americans that is based not so much on race, but rather on ethnicities within the races, particularly when ethnicity may explain fundamental differences in political preferences.

\section{RE F E R E N C E S}

Canon, David T. 1999. Race, Redistricting, and Representation: The Unintended Consequences of Black Majority Districts. Chicago: University of Chicago Press.

Cox, Gary W., and Mathew McCubbins. 2005. Setting the Agenda: Responsible Party Government in the U.S. House of Representatives. Cambridge: Cambridge University Press.

Fenno, Richard F. 200o. Congress at the Grassroots. Chapel Hill: University of North Carolina Press.

- 2003. Going Home: Black Representatives and their Constituents. Chicago: University of Chicago Press.

Hammond, Susan Webb. 1998. Congressional Caucuses in National Policymaking. Baltimore: Johns Hopkins University Press.

Holtz, Carol. 2008. Global Health Care: Issues and Policies. Sudbury: Jones and Bartlett.

Singh, Robert. 1998. The Congressional Black Caucus: Racial Politics in the U.S. Congress. Thousand Oaks: Sage.

Smith, Robert C. 1981. "The Black Congressional Delegation.” Western Political Quarterly 34 (2): 203-21.

Sulkin, Tracy. 2005. Issue Politics in Congress. Cambridge, MA: Cambridge University Press.

Walton, Hanes. 1994. Black Politics and Black Political Behavior: A Linkage Analysis. Westport: Praeger.

Wilson, Jill. 2008. African-Born Blacks in the Washington, D.C., Metro Area. Population Reference Bureau. http://www.prb.org/Articles/2008/blackImmigrantsdc.aspx.

Menna Demessie received her joint Ph.D. in public policy and political science at the University of Michigan in August 2010 and currently teaches as an adjunct professor at the University of Washington California Center. She serves on the Executive Council for the National Conference of Black Political Scientists (NCOBPS) and is the National Youth Coordinator for the Society of Ethiopians Established in the Diaspora (SEED). She can be reached atdemessie@umich.edu. 